\title{
Prospects for the development of organic farming in the Primorsky Territory
}

\author{
Andrey Komin ${ }^{1, *}$, Tatyana Kirtaeva ${ }^{1}$, and Galina Dudenko ${ }^{1}$ \\ ${ }^{1}$ Primorskaya State Academy of Agriculture, 44 Bluhera st., Ussuriisk, Russian Federation, 692510
}

\begin{abstract}
In the modern world, special attention is paid to the rational use of natural resources and the provision of the population with safe food. In this regard, the principles of organic farming are relevant both in Russia and abroad, as they allow reducing the negative impact of agriculture on the environment. Primorsky Territory has a significant potential for the development of organic farming due to the presence of fallow lands and the proximity to the countries of the Asia-Pacific region interested in importing organic products. That is why the development of regional programs in this area will contribute not only to reducing the pesticide load on agroecosystems, but also to the economic growth of the south of the Far East.
\end{abstract}

\section{Introduction}

In the modern world, the intensification of agricultural production based on the use of chemical pesticides and synthetic mineral fertilizers has reached its limits, and the emergence of an organic segment in the agricultural industry of many countries was a reaction to the excessive chemicalization of agricultural production.

According to the annual report of IFOAM, 178 countries practice organic production in the world, of which 87 have their own regulatory framework [3].

According to FiBL and Ecovia Intelligence research company, the global organic food market has surpassed US $\$ 100$ billion (almost $€ 97$ billion) for the first time. According to IFOAM, the top three remained unchanged - the United States leads the market with 40.6 billion euros, followed by Germany (10.9 billion euros) and France (9.1 billion euros) [15].

In terms of the distribution of certified organic agricultural land, Australia and Oceania hold a leading position with a total area of 35.9 million hectares, followed by European countries (14.6 million hectares), and Russia, a country fully provided with land resources, currently has only 0.7 million hectares of land certified for growing organic products (Fig. 1).

\footnotetext{
* Corresponding author: lesfak11@mail.ru
} 


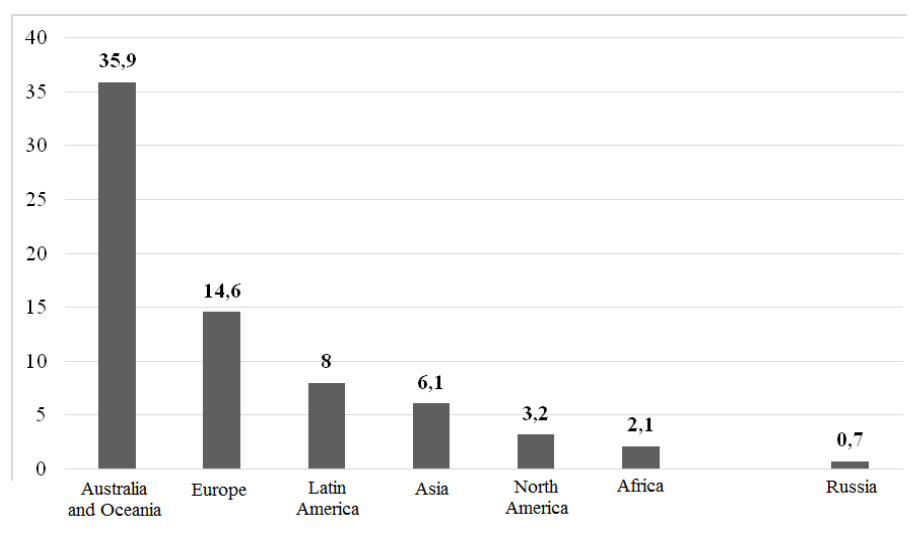

Fig. 1. Distribution of certified organic agricultural land in the world, million hectares (Source: FiBL, 2019).

Since 2018, the Russian Federation has been on the list of countries practicing organic farming, and since January 1, 2020, the production of organic products in our country has been legislatively enshrined after the entry into force of the Federal Law "On Organic Products" [13].

\section{Materials and methods}

After analyzing the literary sources, it was found out that there are many definitions of organic farming, which is called organic, biological, ecological, and other terms. For the first time the term "organic agriculture" was used by Walter Northbourne, considered the founder of this area, in 1940 in his work "Look to the Land". As an equivalent, the term "biological agriculture" is used in Italy, France, Portugal, Holland; in Germany, Spain, Poland, the Czech Republic - "ecological agriculture", in Finland - "natural agriculture" [2].

In Russia, organic agriculture is understood as a set of economic activities in the implementation of which methods, ways and technologies aimed at ensuring a favorable state of the environment, strengthening human health, preserving and restoring soil fertility are used [13].

Organic agriculture is equated to an extensive form of its management if we talk about medium-sized enterprises up to 20 hectares of total area, which is most often observed in European countries, and one can agree with this. But in Russia, certified organic enterprises operate on an area of several thousand hectares - Savinskaya Niva LLC, Biosphere LLC, Efirmaslo LLC, Siberian organic products LLC, Plemreproduktor Vasilyevskoe CJSC, Nova Russa LLC and others. And despite the fact that the Russian Federation takes only 135th place in terms of the number of producers, it strives to become the world leaders in terms of the volume of certified lands (14th place) [10].

Organic farming is not only the greening of agriculture, which implies the rejection of the use of mineral fertilizers and chemicals, but also the economic sector, which is rapidly developing and is in demand among other global trends in the agricultural industry. The market for organic products is growing every year both in our country and abroad. This is due to a number of factors. However, the most interesting of them is that organic farming stimulates and enhances the well-being of the agricultural ecosystem, including biodiversity, biological cycles and biological activity of the soil, which is achieved by using 
all possible agronomic, biological and mechanical methods, as opposed to the use of synthetic materials [14].

Russia has resources for the production of organic products. First of all, these are the traditions of extensive use of large areas of land, a low level of intensification and chemicalization in comparison with industrially developed countries. If in general in the countries of the European Union the application of mineral fertilizers is $192 \mathrm{~kg} / \mathrm{ha}$, then in Russia - $39 \mathrm{~kg} / \mathrm{ha}$. All this makes the problem of the use of land resources by technologies focused on the production of organic products relevant, involving for these purposes fallow and unused agricultural land resources in the production turnover [5].

Primorsky Territory is located in the south of the Far East and occupies 164.7 thousand $\mathrm{km}^{2}$, which is about $1 \%$ of the area of the Russian Federation. As of January 1, 2020, the area of agricultural land in the region amounted to $1,860.5$ thousand hectares, of which the area of agricultural land (arable land, fallow lands, hayfields, pastures, perennial plantations) - 1398.8 thousand hectares, and only 484 thousand hectares are sown area $[9,11]$. Thus, about $50 \%$ of agricultural land is potential for development and use for growing crops, taking into account the principles of organic farming.

Different intensity of land use in combination with complex natural and economic factors, of which soil and climatic conditions, strong anthropogenic impact are of particular importance, have largely changed the natural direction of processes in nature and led to the degradation of soil and vegetation cover over a large area [12].

The lands of the Primorsky Territory are mostly erosion-hazardous. This is due to the natural properties of the soils themselves, their occurrence and distribution patterns in natural landscapes, as well as the influence of the climatic conditions of the Primorsky Territory. Agricultural lands are located mainly in mountain-valley areas, in the floodplains of a branched network of rivers, where soils are subject to intense river erosion with the formation of ravines [7, 8].

Of particular interest in the production of organic products are fallow lands, the area of which in the region is currently more than 100 thousand hectares [4]. Their introduction into agricultural circulation is the simplest and least costly way to increase the area of productive arable land, as well as one of the innovative directions in the country's economy to address the issues of import substitution.

In addition, a great advantage over other agricultural producers in the country is the proximity of the Primorsky Territory to the countries of the Asia-Pacific region, which are interested in importing high-quality organic products. Currently, the demand for this type of product in these countries exceeds the supply. Thus, China ranks 4 th among the countries with the highest consumption of organic products and retail sales of 7.6 million euros (Fig. 2).

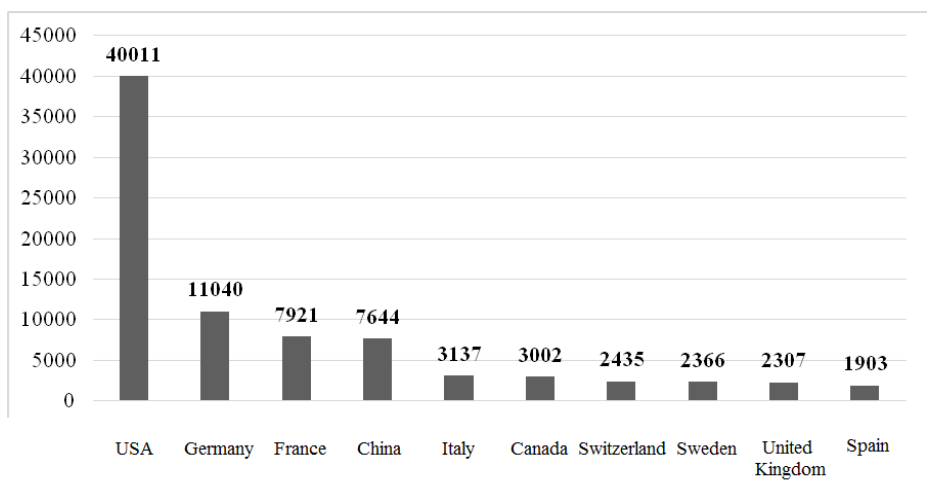

Fig. 2. Countries with the highest consumption of organic products, retail sales in million euros (Source: FiBL, 2019). 
The undoubted leader in the consumption of organic products was and is Japan, since its population consumes about $44 \%$ of the total Asian volume of organic products sold.

The development of cooperation between Russia and South Korea in the field of agriculture, including organic agriculture, was facilitated by the Russian-Korean Seminar on food safety, certification and promotion of Korean food products to the Russian market organized by the Korean-Russian Business Council in cooperation with Moscow State University of Food Production (MSUFP) with the support of the Ministry of Industry, Trade and Energy of the Republic of Korea [1]. Further cooperation will allow not only expanding the access of Korean products to the Russian market, but will also contribute to the promotion of Russian organic agricultural products in the market of our partners. And as trade in organic agricultural products increases, it will be expedient to create a joint Russian-Korean center for certification of such products.

In order to substantiate the directions for the development of agricultural production of organic products, it seems expedient to know the factors that contribute to the development of the organic food market at the following levels: state, regional and micro-level of enterprises and organizations (Table 1).

And if at the federal level, with the introduction of the Federal Law "On Organic Products" in our country, there is a stable growth of agricultural enterprises whose main activity is the production of organic products, then at the regional and level of agricultural enterprises in the Primorsky Territory, there are significant gaps.

This is primarily due to the lack of a regional target program for the development of organic farming and, accordingly, due to all the ensuing consequences: difficulties in investing projects oriented towards organic production in the agricultural industry; lack of motivation and interest in organic production on the part of heads of agricultural enterprises; lack of a market for organic products; lack of qualified specialists in the field of organic land use and difficulties in certification of organic products.

The activities of the regional program for the development of organic farming in the Primorsky Territory will be aimed at increasing the efficiency of agricultural production and creating the prerequisites for ensuring food security in both Primorsky Territory and the Russian Federation as a whole by increasing the volume of organic agricultural products.

The expected results of the implementation of program activities are: the reproduction of soil fertility of arable land; involvement in agricultural production of fallow lands in order to develop organic farming; improving the economic situation in the region due to the production and import of organic products.

In addition, other activities may also be important for the development of organic farming: the creation of groups and organizations of organic producers and their cooperation; knowledge transfer and communication (support for training and skills acquisition); consulting services in the field of creation and management of agricultural enterprises, producers of organic products; assistance in starting a business for young farmers.

The basis of organic agriculture could be small individual farms of the region, which, having passed certification, will be able to increase the total volume of production and the territory of organic farming. However, it should be remembered that the conditions for the production and sale of organic products have their own specifics: organic farming is more labor-intensive than intensive agricultural production, since the level of mechanization is reduced in it; the yield of agricultural crops is lower, which undoubtedly affects the cost of production; additional costs for organic and biological fertilizers, as well as biological plant protection products; the procedure for certification of lands and products requires additional costs. 
Table 1. Organizational levels and determinants of the development of agriculture focused on the production of organic products.

\begin{tabular}{|c|c|}
\hline $\begin{array}{l}\text { Organizational } \\
\text { level }\end{array}$ & $\begin{array}{l}\begin{array}{c}\text { Determinants of the development of agriculture towards the production of } \\
\text { organic products }\end{array}\end{array}$ \\
\hline \multirow{4}{*}{ Federal } & $\begin{array}{l}\text { Preparation and adoption of regulatory documents regulating the concepts } \\
\text { of "organic, environmentally friendly (safe) products", "organic product" }\end{array}$ \\
\hline & $\begin{array}{l}\text { Formation of a regulatory framework governing the functioning of the } \\
\text { market for organic products in the interests of consumers, based on the } \\
\text { participation of all interested market actors }\end{array}$ \\
\hline & $\begin{array}{l}\text { Development of a system of national standards in the field of greening } \\
\text { agriculture, as well as their harmonization with the system of } \\
\text { international environmental standards }\end{array}$ \\
\hline & $\begin{array}{l}\text { Development of an economic mechanism to stimulate producers of } \\
\text { organic products through a system of preferential lending, optimization of } \\
\text { taxation, the direction of grants and subsidies, in general, increasing the } \\
\text { investment and innovative attractiveness of the subjects of the organic } \\
\text { products market }\end{array}$ \\
\hline \multirow{5}{*}{ Regional } & $\begin{array}{l}\text { Development of targeted programs to support the formation and } \\
\text { development of agriculture focused on the production of organic } \\
\text { products. Development of a regulatory framework for agricultural } \\
\text { production of organic products that does not contradict federal legislation. }\end{array}$ \\
\hline & $\begin{array}{l}\text { Conducting scientific research to identify the potential for organic land } \\
\text { use in the region. Expansion of the information field covering the features } \\
\text { of agricultural production of organic products. }\end{array}$ \\
\hline & $\begin{array}{l}\text { Formation of educational programs for personnel training and } \\
\text { advanced training of specialists in the field of agriculture focused on the } \\
\text { production of organic products }\end{array}$ \\
\hline & $\begin{array}{l}\text { Involvement of land resources in the production turnover, } \\
\text { suitable for the production of organic products. Formation of zonal } \\
\text { agroecoclusters. }\end{array}$ \\
\hline & $\begin{array}{l}\text { Development of regional markets for organic products. Participation in } \\
\text { international and Russian exhibitions and fairs in order to promote } \\
\text { regional organic products }\end{array}$ \\
\hline \multirow{4}{*}{$\begin{array}{l}\text { Level of Agriculture } \\
\text { Enterprises }\end{array}$} & $\begin{array}{l}\text { Choosing the direction of the transition to the production of organic } \\
\text { products, taking into account the available production resources and the } \\
\text { demand for organic products }\end{array}$ \\
\hline & $\begin{array}{l}\text { Reproduction of land resources through the involvement of unused and } \\
\text { fallow lands in agricultural circulation, restoration of soil fertility and the } \\
\text { transition to greening land use }\end{array}$ \\
\hline & $\begin{array}{l}\text { Improving the efficiency of agricultural production due to higher selling } \\
\text { prices for organic products }\end{array}$ \\
\hline & $\begin{array}{l}\text { Entry of the organization into the structure of the zonal agroecocluster. } \\
\text { Training and professional development of personnel. Certification of the } \\
\text { organic production system }\end{array}$ \\
\hline
\end{tabular}

In connection with the above stated, the initial period of organic production, as a rule, can be unprofitable. However, over time, the main competitive advantage comes into play the quality of products demanded by the growing market, the cost of which is $30-40 \%$ higher than products manufactured using traditional technologies.

The first steps in the development of organic farming in the Primorsky Territory have already been made. So, in the fall of 2019, the heads of the leading farms of the region were trained under the program "Organic agricultural products according to the JAS standard", which was organized by representatives of the Japanese company ECOCERT Japan Ltd. (Fig. 3). 


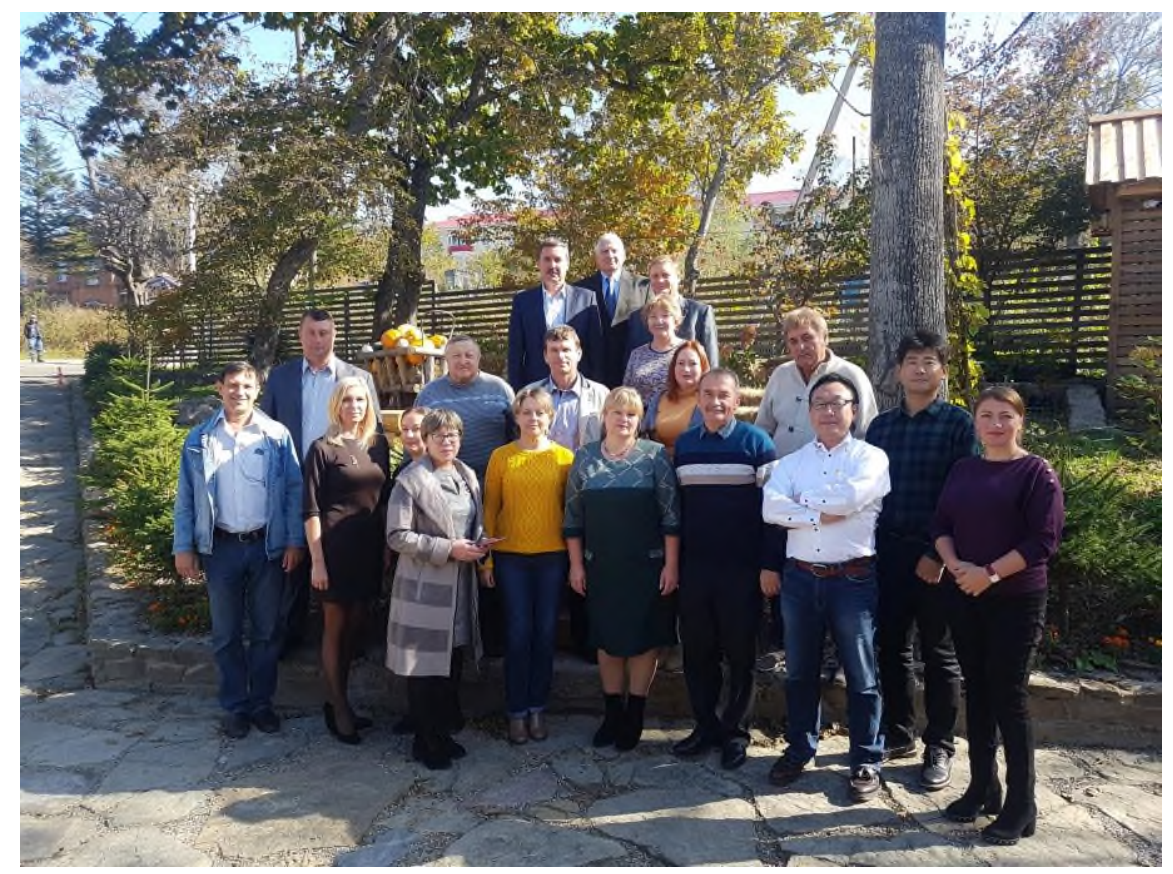

Fig. 3. Participants of the program "Organic agricultural products according to the JAS standard" (Vladivostok, 2019).

And already in the spring of 2020, such agricultural enterprises of the Partizansky District of the Primorsky Territory as Agrofond-P LLC (Novaya Sila settlement, $230 \mathrm{ha}$ ), T.A. Morozova peasant farm (Frolovka village, 217.5 ha) and Grishko A.I. peasant farm (Sergeevka village, $166 \mathrm{ha}$ ) certified the land and started the production of organic products for subsequent import to Japan (Fig. 4).
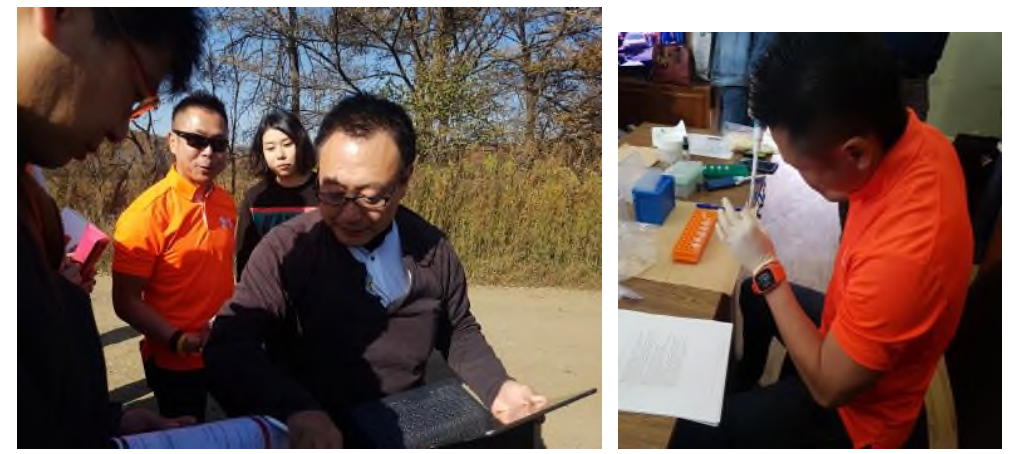

Fig. 4. Sampling of soil samples for subsequent certification according to the JAS standard by representatives of the University of Tsukuba (Japan), 2019 (Partizansky district, Morozova T.A. peasant farm).

Nowadays, these farms, taking into account the principles of organic farming, cultivate grain (Glycine max, Zea mays, Avena sativa) and vegetable (Cucurbita pepo, Daucus sativus, Beta vulgaris) crops.

An analysis of available publications and world experience allows concluding that the development of organic farming both in the country and in the region should be considered as an important resource of the agricultural economy and the Russian economy as a whole. 


\section{Conclusion}

Organic agriculture is a holistic system for producing high quality food. The Primorsky Territory has all the necessary resources for the production of organic products, which can ensure the economic well-being of the inhabitants of the region, provided that competent management and state support are organized. To further expand the organic sector in the region, first of all, it is necessary to develop a regional target program, develop economic incentives to attract more farmers to the category of "organic farming", as well as raise awareness of both agricultural producers and consumers about the importance of organic methods of farming. Agrarian universities should provide training of specialists in this area.

\section{References}

1. T.V. Akhmadulina, A.A. Grishkova Development of cooperation between Russia and the Republic of Korea in the field of agriculture, Young scientist,14 (94), 219-222. (2015)

2. E.V. Borodastova, The history of the formation and development of organic farming in Russia, Agroforsayt, 6, 5 (2016)

3. Annual consolidated report of IFOAM (2017)

4. Results of the All-Russian agricultural census of 2016 in the Primorsky Territory: Land resources and their use. Collection. 3, 125 p (2018)

5. V.I. Kenikstul, G.V. Noskova Land resources of Russia - an effective management and control system, Agribusiness: Economics, Management, 6, 22-27 (2012)

6. V.A. Kundius, O.Yu. Voronkova, I.V. Kovaleva Production of organic products on fallow lands of Siberian regions as a strategic resource of the policy of import substitution of food, Socio-economic and humanitarian journal of Krasnoyarsk State Agrarian University, 2, 25-41 (2017)

7. T.V. Naumova, N.V. Mukhina, M.M. Surzhik, Erosion assessment of arable land in the farms of the Primorsky Territory, Trends in the development of science and education, 64-2, 14-18 (2020)

8. M.V. Nesterenko Analysis of agricultural land resources in the Primorsky Territory, Vestnik of the Pacific State University of Economics, 3, 23-32 (2007)

9. On the ecological situation in the Primorsky Territory. Analytical note, Primorskstat, 44 (2020)

10. Organization of organic agricultural production in Russia: inform,124 (2018)

11. S. A. Chunikhin, E. A. Kuzmin, L. V. Pushkareva, Entrepreneurship and Sustainability Issues 6(4), 1663-1679 (2019) doi:10.9770/jesi.2019.6.4(8)

12. Yu.I. Slabko Achievements of agricultural science and problems of their use in modern conditions of agriculture in the Primorsky Territory, Vestnik of the Far Eastern Branch of the Russian Academy of Sciences, 3, 23-26 (2018)

13. Federal Law 280-FZ On organic products and on amendments to certain legislative acts of the Russian Federation

14. K.A. Yakubenkova Legal regulation of organic farming, Scientific support of the agricultural industry: Collection of articles based on the materials of the XAll-Russian conference of young scientists dedicated to the 120th anniversary of I. S. Kosenko, 858-859 (2017) 